\title{
Natural history of mevalonate kinase deficiency: a literature review
}

\author{
Shumin Zhang
}

\begin{abstract}
Mevalonate kinase deficiency (MKD), a very rare autosomal recessive autoinflammatory disease with multiple organ involvement, presents clinically as hyperimmunoglobulinemia D syndrome (HIDS), a less severe phenotype and more common form, and mevalonic aciduria (MVA), a more severe phenotype and rare form. MKD is characterized by recurrent febrile attacks that are frequently accompanied by lymphadenopathy, gastrointestinal symptoms, arthralgia, myalgia, skin rash, and aphthous ulcers. Patients with MVA also have intrauterine growth retardation, congenital defects (cataracts, shortened limbs, and dysmorphic craniofacial features), neurological disease, and failure to thrive. Mean age at onset of symptoms is within the first year of life. There is a delay by several years between symptom onset and diagnosis, which is in part attributable to the initial misdiagnosis due to the rarity and nonspecific clinical manifestations of disease. The frequency of recurrent febrile attacks is highest in childhood and gradually decreases after adolescence. MKD is associated with rare long-term complications such as type AA amyloidosis, joint contractures, abdominal adhesions, renal angiomyolipoma, and severe pneumococcal infections. Frequent febrile attacks significantly impair several aspects of patients' and caregivers' quality of life, with an adverse impact on patients' daily activities, education, and employment. Lifespan is generally normal for HIDS whereas MVA can be fatal in early childhood.
\end{abstract}

Keywords: Mevalonate kinase deficiency, Rare diseases, Hereditary autoinflammatory diseases, Hyperimmunoglobulinemia D, Mevalonic aciduria

\section{Background}

Mevalonate kinase deficiency (MKD) is a very rare, autosomal recessive autoinflammatory disease with multiple organ involvement $[1,2]$. MKD is caused by mutations in the gene encoding mevalonate kinase (MVK) leading to reduced or deficient activity of mevalonate kinase. MKD presents clinically as hyperimmunoglobulinemia D syndrome (HIDS), a less severe phenotype and more common form, and mevalonic aciduria (MVA), a more severe phenotype and rare form [1].

Autoinflammatory diseases like MKD represent an area of high unmet needs as there are no approved treatments for many of these conditions. A disease's natural history data can shed light on its prevalence, incidence, clinical features, complications, progression, and potential biomarkers. According to the book of Rare Diseases Epidemiology [3], a disease's natural history is "the natural course of a disease from the time immediately prior to its inception, progressing through its presymptomatic phase and different clinical stages to the point where it has ended and the patient is either cured, chronically disabled or dead without external intervention." Data on the disease's natural history can also inform the clinical trial design (e.g., patient numbers and types, study duration, and selection of biomarkers and endpoints) [4]. In clinical development for rare diseases, natural history data may also possibly be used as a historical comparator when the observed treatment effect in the clinical trial is considerably greater than variability in disease course [4]. This review summarized the existing literature related to MKD natural history. Search of literature published in English was carried out primarily in PubMed (US National Library of Medicine) using $\mathrm{MeSH}$ terms and free text and by checking key references in relevant publications.

Correspondence: shumin.zhang@takeda.com

Epidemiology, Takeda Development Center Americas, Inc., One Takeda

Parkway, Deerfield, IL 60015, USA

(c) 2016 Zhang. Open Access This article is distributed under the terms of the Creative Commons Attribution 4.0 International License (http://creativecommons.org/licenses/by/4.0/), which permits unrestricted use, distribution, and reproduction in any medium, provided you give appropriate credit to the original author(s) and the source, provide a link to the Creative Commons license, and indicate if changes were made. The Creative Commons Public Domain Dedication waiver (http:// creativecommons.org/publicdomain/zero/1.0/) applies to the data made available in this article, unless otherwise stated. 


\section{Prevalence and incidence}

MKD is considered an 'ultra-rare' condition. Worldwide, approximately 300 patients have been reported $[1,5]$, including approximately 30 patients with MVA [6, 7]. This is likely an underestimate of the population of MKD since some patients may never get diagnosed due to the lack of genetic screening programs for MKD and since not all diagnosed patients may ever be reported to rare disease registries or in the literature [1].

The vast majority of reported patients are European or of European ancestry [2, 8-14], with the largest cluster in the Netherlands and western Europe [1, 14]. About 80 patients with HIDS have been reported from the Netherlands [11], where the founder mutation (p.Val377Ile) is believed to have originated $[14,15]$. The Netherlands also has a higher awareness for HIDS, especially with the inclusion of the measurement of immunoglobulin D (IgD) levels in the diagnostic work-up of patients with periodic fever [14]. Only 20 HIDS cases from the United States (US) have been submitted to the international HIDS database [8], which included cases diagnosed up to January 2007 and thus likely underrepresented the current US HIDS patient population.

Data on the prevalence and incidence of MKD are sparse. No published data are available in the US. There are 3 published reports, all in European populations [11, 13, 16], providing the prevalence estimate ranging from 1.3 per 1,000,000 for MKD in Eastern and Central European countries in children aged $0-19$ years to 5 per $1,000,000$ for HIDS in the whole population in the Netherlands to 6.2 per 1,000,000 for HIDS in Germany in children aged $\leq 16$ years. The incidence of HIDS is also very low with an estimate of 0.39 (95\% confidence interval: $0.22,0.64)$ per $1,000,000$ person-years in Germany in children aged $\leq 16$ years [16].

\section{Follow-up studies of natural history}

Table 1 summarizes the demographic and clinical characteristics of patients in four largest natural history studies, including the International HIDS Database, a completed, long-term follow-up study of 103 patients with HIDS (excluding patients with MVA) from 18 countries [8], a retrospective French and Belgian chart review of 50 patients with MKD [2], a long-term followup of a cohort of 56 patients with MKD in Italy [9], and the Eurofever registry, an ongoing, web-based, international, retrospective follow-up study of autoinflammatory diseases with 114 patients with MKD from 33 countries $[5,10,17,18]$.

Genetic mutations and genotype-phenotype relationship To date, 204 MVK sequence variants have been submitted to the Infevers, an online registry of hereditary autoinflammatory disorders mutations [19-21]. Most patients with MKD are compound heterozygotes for missense mutations [2, 22]. Other mutations include nonsense mutations, deletions, insertions, splicing defects, and a combination of a deletion and an insertion $[2,23]$. The p.Val377Ile mutation was the most common MVK gene mutation with approximately $50 \%$ of allele frequency among patients $[2,5,8,9,22]$ (Table 1 ). The p.Val377Ile mutation was found to be present only in the HIDS phenotype in an earlier study [23]. However, in a more recent French and Belgian study, 6 patients homozygous for p.Val377Ile had variable severities of MKD ranging from asymptomatic, to mild, to severe [2]. The p.Ile268Thr mutation was the second most frequent MVK gene mutation with approximately $8-15 \%$ of allele frequency among patients $[2,5,8,22,23]$ (Table 1 ). The p.Ile268Thr mutation was found to be present in both HIDS and MVA phenotypes [23]. No relationship was observed between genotypes and the phenotype with respect to age at onset of symptoms, symptoms during febrile attacks, and the frequency of febrile attacks per year in the International HIDS Database [8, 24].

Mevalonate kinase is a key enzyme of the mevalonate pathway that produces isopentenyl pyrophosphate (IPP), downstream compounds of non-sterol isoprenoids such as farnesyl-pyrophosphate and geranylgeranyl-pyrophosphate, and cholesterol [1, 25]. The mutation in MVK results in reduced activity of mevalonate kinase, which in turn leads to decreased production of IPP and non-sterol isoprenoids and an accumulation of mevalonate [1]. IPP and non-sterol isoprenoids are important for various key physiological processes, including inflammatory pathways. Clinical manifestations of MKD have initially been hypothesized to be due to high levels of mevalonate. Recent data indicate that reduced availability of non-sterol isoprenoids play a critical role in the inflammatory phenotype of MKD, which is at least in part mediated through interleukin (IL)-1 $\beta$ [1].

\section{Clinical features and progression of disease}

While the average age at onset of symptoms of MKD is within the first year of life, and before age 5 for the vast majority of the patients (2), it could vary from the first week of life to 20 years [2, 8-10] (Table 1). However, the median age at diagnosis is about 8 to 10 years, suggesting a delay by several years between symptom onset and diagnosis. This can be in part attributable to the initial misdiagnosis due to its rarity and the nonspecific nature of the clinical disease manifestations $[8,10,26]$. In the International HIDS Database, 33 of the 103 patients were offered an alternative diagnosis (Familial Mediterranean Fever [13 patients], adult-onset Still disease [6 patients], juvenile chronic arthritis [ 5 patients], rheumatic fever [3 patients], chronic infection [3 patients], and Behçet disease [3 patients]) before the diagnosis of HIDS [8]. Similarly, many diseases had been considered before the right 
Table 1 Summary of demographic and clinical characteristics of patients with MKD

\begin{tabular}{|c|c|c|c|c|c|}
\hline Author & van der Hilst et al. [8] & \multicolumn{2}{|c|}{ Bader-Meunier et al. [2] } & Doglio et al. [9] & $\begin{array}{l}\text { Jeyaratnam et al. [17], Toplak et al. [10] } \\
\text { Ter Haar et al. [5] }\end{array}$ \\
\hline Study & $\begin{array}{l}\text { International HIDS } \\
\text { Database }\end{array}$ & \multicolumn{2}{|c|}{ France/Belgium } & Italy & International Eurofever Registry \\
\hline Study design & $\begin{array}{l}\text { Retrospective follow- } \\
\text { up }\end{array}$ & \multicolumn{2}{|c|}{ Retrospective follow-up } & $\begin{array}{l}\text { Prospective follow- } \\
\text { up }\end{array}$ & Retrospective follow-up \\
\hline Study period & 1994-2007 & \multicolumn{2}{|l|}{ 1999-2010 } & N/A & $2009-2011^{a}$ \\
\hline Length of follow-up, years & 14 & \multicolumn{2}{|c|}{ Not specified } & $\begin{array}{l}\text { Long-term } \\
\text { (not specified) }\end{array}$ & 11.5 \\
\hline Number of patients & 103 HIDS & \multicolumn{2}{|l|}{$50 \mathrm{MKD}$} & $56 \mathrm{MKD}$ & 114 MKD \\
\hline $\begin{array}{l}\text { Most common MVK mutation (allele } \\
\text { frequency in patients) }\end{array}$ & p.Val377lle (50 \%) & \multicolumn{2}{|c|}{ p.Val377lle (43\%) } & p.Val377lle (47\%) & p.Val377lle (48 \%) \\
\hline $\begin{array}{l}2^{\text {nd }} \text { most common MVK mutation } \\
\text { (allele frequency in patients) }\end{array}$ & p.lle268Thr (15\%) & \multicolumn{2}{|c|}{ p.lle268Thr (8 \%) } & N/A & p.lle268Thr (13\%) \\
\hline $\begin{array}{l}\text { Age of patients, years, median or } \\
\text { mean } \pm S D \text { (range) }\end{array}$ & $19(2,74)$ & \multicolumn{2}{|c|}{$\begin{array}{l}19.5(0.6,58) \text { at last } \\
\text { visit }\end{array}$} & $\begin{array}{l}13.3 \pm 8.5 \text { at follow- } \\
\text { up }\end{array}$ & $14^{a}(1,60)^{a}$ \\
\hline$\%$ of patients aged $<18$ years & N/A & \multicolumn{2}{|l|}{$\mathrm{N} / \mathrm{A}$} & $\mathrm{N} / \mathrm{A}$ & $63 \%^{a}$ \\
\hline $\begin{array}{l}\text { Age at onset of symptoms, months, } \\
\text { median or mean } \pm S D \text { (range) }\end{array}$ & $6(0,120)$ & \multicolumn{2}{|c|}{4 (1 day, 240 months) } & $\begin{array}{l}10.5 \pm 15.3 \\
(1,108)\end{array}$ & $6(\sim 0, \sim 72)^{a}$ \\
\hline $\begin{array}{l}\% \text { of patients who had the first } \\
\text { attack within the first year of life }\end{array}$ & $78 \%$ & \multicolumn{2}{|l|}{ N/A } & N/A & $71 \%{ }^{b}$ \\
\hline $\begin{array}{l}\% \text { of patients who had the first } \\
\text { attack before the age of } 5 \text { years }\end{array}$ & N/A & \multicolumn{2}{|l|}{$92 \%$} & N/A & N/A \\
\hline $\begin{array}{l}\text { Age at diagnosis, years, median } \\
\text { (range) }\end{array}$ & $\begin{array}{l}10 \text { ( }<3 \text { months, } \\
52 \text { years) }\end{array}$ & \multicolumn{2}{|l|}{$\mathrm{N} / \mathrm{A}$} & $\mathrm{N} / \mathrm{A}$ & $\sim 8^{\mathrm{a}}(\sim 3 \text { months, } \sim 29 \text { years })^{\mathrm{a}}$ \\
\hline $\begin{array}{l}\text { Duration from onset to diagnosis, } \\
\text { years, median (range) }\end{array}$ & 9.9 & \multicolumn{2}{|l|}{ N/A } & N/A & $2.5^{\mathrm{a}}(0.1-8.3)^{\mathrm{a}}$ \\
\hline $\begin{array}{l}\text { Disease duration, years, mean } \pm S D \\
\text { (range) }\end{array}$ & N/A & \multicolumn{2}{|c|}{$\begin{array}{l}24(1,55) \text { from the } \\
\text { onset to most recent } \\
\text { assessment }\end{array}$} & $12.4 \pm 8.7$ & $13.1^{\mathrm{b}}$ at enrollment \\
\hline Sex, $\%$ of men & $50 \%$ & \multicolumn{2}{|l|}{$42 \%$} & $52 \%$ & $46 \%$ \\
\hline Ethnicity & N/A & \multicolumn{2}{|c|}{ White, $69 \%$} & N/A & Caucasian, $90 \%$ \\
\hline Positive family history, \% & N/A & \multicolumn{2}{|l|}{ N/A } & N/A & $26 \%^{a}$ \\
\hline $\begin{array}{l}\% \text { of patients with }>12 \text { fever } \\
\text { episodes/year }\end{array}$ & $\begin{array}{l}44 \% \text {, aged } 0-10 \text { year } \\
24 \% \text {, aged } 11- \\
20 \text { year } \\
18 \% \text {, aged }>20 \text { year }\end{array}$ & \multicolumn{2}{|c|}{$76 \%$ at the onset } & N/A & N/A \\
\hline $\begin{array}{l}\text { Number of fever episodes per year, } \\
\text { mean } \pm S D \text { (min, max) or median }\end{array}$ & N/A & \multicolumn{2}{|l|}{ N/A } & $\begin{array}{l}13.8 \pm 5.4 \\
(3,30) \text { at baseline } \\
8.8 \pm 6.7 \text { at follow-up }\end{array}$ & 12 \\
\hline $\begin{array}{l}\text { Duration of fever episodes, days, } \\
\text { mean (range) or median }\end{array}$ & N/A & \multicolumn{2}{|l|}{$3.7(1,10)$} & N/A & 5 (3 to 7 in $81 \%$ of the patients) ${ }^{b}$ \\
\hline $\begin{array}{l}\text { Precipitating factors of fever } \\
\text { episodes, } \%\end{array}$ & & & & N/A & \\
\hline Vaccination & $\begin{array}{l}63 \% \text { for the } 1 \text { st } \\
\text { attack }\end{array}$ & N/A & & & $36 \%$ \\
\hline Infection & N/A & N/A & & & $17 \%$ \\
\hline Infection and/or vaccination & N/A & $42 \%$ & & & N/A \\
\hline Stress & $\begin{array}{l}\text { Many cases (not } \\
\text { specified) }\end{array}$ & N/A & & & $24 \%$ \\
\hline $\begin{array}{l}\text { Signs and symptoms during febrile } \\
\text { attacks, \% }\end{array}$ & & $\begin{array}{l}\text { Estimated } \\
\%\end{array}$ & $\begin{array}{l}\text { Estimated } \\
\%\end{array}$ & N/A & \\
\hline Gastrointestinal/abdominal & & Onset & Cumulative & & \\
\hline Abdominal pain & $85 \%$ & $20 \%$ & $63 \%$ & & $88 \%$ \\
\hline
\end{tabular}


Table 1 Summary of demographic and clinical characteristics of patients with MKD (Continued)

\begin{tabular}{|c|c|c|c|c|}
\hline Diarrhea & $72 \%$ & $40 \%$ & $69 \%$ & $84 \%$ \\
\hline Vomiting & $71 \%$ & $11 \%$ & $45 \%$ & $69 \%$ \\
\hline Hepatomegaly & $22 \%$ & $25 \%$ & $37 \%$ & N/A \\
\hline Serositis & $19 \%$ & N/A & N/A & N/A \\
\hline Pericarditis & N/A & $0 \%$ & $4 \%$ & N/A \\
\hline \multicolumn{5}{|l|}{ Lymphoid tissue } \\
\hline Lymphadenopathy & $87 \%$ & $38 \%$ & $71 \%$ & $84 \%^{b}$ \\
\hline Splenomegaly & $32 \%$ & $32 \%$ & $63 \%$ & N/A \\
\hline \multicolumn{5}{|l|}{ Musculoskeletal } \\
\hline Arthralgia & $84 \%$ & $20 \%$ & $67 \%$ & $71 \%$ \\
\hline Arthritis & $55 \%$ & $6 \%$ & $43 \%$ & $28 \%$ \\
\hline Myalgia & N/A & $0 \%$ & $22 \%$ & $57 \%$ \\
\hline \multicolumn{5}{|l|}{ Cutaneous and mucocutaneous } \\
\hline $\begin{array}{l}\text { Skin lesions or maculopapular } \\
\text { rash }\end{array}$ & $69 \%$ & $43 \%$ & $67 \%$ & $39 \%$ \\
\hline Aphthous ulcers or stomatitis & $49 \%$ & $15 \%$ & $43 \%$ & $60 \%$ \\
\hline Pharyngitis & N/A & N/A & N/A & $28 \%$ \\
\hline \multicolumn{5}{|l|}{ General } \\
\hline Cold chills & $63 \%$ & $\mathrm{~N} / \mathrm{A}$ & N/A & $\mathrm{N} / \mathrm{A}$ \\
\hline Headache & $63 \%$ & $0 \%$ & $12 \%$ & $38 \%$ \\
\hline Malaise & N/A & N/A & N/A & $65 \%$ \\
\hline Weight loss & N/A & $\mathrm{N} / \mathrm{A}$ & N/A & $66 \%$ \\
\hline Fatigue & N/A & $\mathrm{N} / \mathrm{A}$ & $\mathrm{N} / \mathrm{A}$ & $63 \%$ \\
\hline Mood disorders & N/A & N/A & N/A & $24 \%$ \\
\hline Thrombocytopenia & $\mathrm{N} / \mathrm{A}$ & $4 \%$ & $4 \%$ & N/A \\
\hline Macrophage activation syndrome & N/A & $0 \%$ & $6 \%$ & $1 \%$ \\
\hline Associated long-term conditions, \% & & & N/A & \\
\hline AA amyloidosis & $3 \%$ & $0 \%$ & & $5 \%$ \\
\hline Abdominal adhesions & $10 \%$ & $6 \%$ & & N/A \\
\hline Joint contractures & $4 \%$ & N/A & & N/A \\
\hline Recurrent and/or severe infections & N/A & $27 \%$ & & $\mathrm{~N} / \mathrm{A}$ \\
\hline Severe pneumococcal infections & $1 \%$ & $6 \%$ & & N/A \\
\hline Hypogammaglobulinemia & $\mathrm{N} / \mathrm{A}$ & $6 \%$ & & $\mathrm{~N} / \mathrm{A}$ \\
\hline Renal angiomyolipoma & $\mathrm{N} / \mathrm{A}$ & $6 \%$ & & $\mathrm{~N} / \mathrm{A}$ \\
\hline Cerebellar syndrome & N/A & $\mathrm{N} / \mathrm{A}$ & & $3 \%$ \\
\hline Seizures & $\mathrm{N} / \mathrm{A}$ & $\mathrm{N} / \mathrm{A}$ & & $5 \%$ \\
\hline Mental retardation & N/A & $2 \%$ & & $4 \%$ \\
\hline $\begin{array}{l}\text { Chronic neurologic, abdominal, } \\
\text { renal, pulmonary, endocrine, } \\
\text { cutaneous, ocular, or hematologic } \\
\text { involvement, erosive polyarthritis, } \\
\text { and/or Sjögren's syndrome }\end{array}$ & N/A & $55 \%$ & & N/A \\
\hline $\begin{array}{l}\text { Biomarkers, median (range), } \% \text { of the } \\
\text { patients above the upper limit of } \\
\text { the [normal value] }\end{array}$ & & & N/A & \\
\hline $\begin{array}{l}\text { WBC count, } \times 10^{9} / L \text { during fever } \\
\text { episodes }[4-8]\end{array}$ & $\begin{array}{l}15, \uparrow \text { in } 100 \% \text { of the } \\
\text { patients }\end{array}$ & $18(7.5-59)$ & & $\uparrow$ in $66 \%$ of tested patients \\
\hline
\end{tabular}


Table 1 Summary of demographic and clinical characteristics of patients with MKD (Continued)

\begin{tabular}{|c|c|c|c|}
\hline $\begin{array}{l}\text { CRP, mg/L during fever episodes } \\
{[<5]}\end{array}$ & $\begin{array}{l}163(36-404), \uparrow \text { in } \\
100 \% \text { of the } \\
\text { patients }\end{array}$ & $\begin{array}{l}157(47-440), \uparrow \text { in } \\
100 \% \text { of tested } \\
\text { patients }\end{array}$ & \\
\hline $\begin{array}{l}\text { ESR mm/hour during fever } \\
\text { episodes }[<10]\end{array}$ & $\begin{array}{l}76, \uparrow \text { in } 100 \% \text { of the } \\
\text { patients }\end{array}$ & $\begin{array}{l}64(27-120), \uparrow \text { in } 100 \% \\
\text { of tested patients }\end{array}$ & $\uparrow$ in $98 \%$ of tested patients \\
\hline $\lg A, g / L[0.5-3.4]$ & $\begin{array}{l}4.1,64 \% \text { of tested } \\
\text { patients }>2.6 \mathrm{~g} / \mathrm{L}\end{array}$ & $\begin{array}{l}4.8(0.25-20.9), 57 \% \text { of } \\
\text { tested patients }>3 \mathrm{~g} / \mathrm{L}\end{array}$ & N/A \\
\hline $\operatorname{lgD}, I U / m L[<100]$ & $\begin{array}{l}400(<0.8-5300), \uparrow \text { in } \\
78 \% \text { of the patients }\end{array}$ & $\begin{array}{l}760(0-2500), \uparrow \text { in } 88 \% \\
\text { of tested patients }\end{array}$ & $\uparrow$ in $72 \%$ of tested patients \\
\hline $\begin{array}{l}\text { Urinary mevalonic acid, mmol/ } \\
\text { mol creatinine during fever } \\
\text { episodes }[<1]\end{array}$ & N/A & $\begin{array}{l}17(2.8-10000), \uparrow \text { in } \\
100 \% \text { of tested } \\
\text { patients }\end{array}$ & $\uparrow$ in $93 \%$ of tested patients \\
\hline \multicolumn{4}{|l|}{$\begin{array}{l}\text { Biomarkers, median (range), } \% \text { of the } \\
\text { patients below the limit of the } \\
\text { [normal value] }\end{array}$} \\
\hline MVK activity, \% of control cells [>25] & N/A & $\begin{array}{l}2.6(0-24), \downarrow \text { in } 100 \% \quad \text { N/A } \\
\text { of tested patients }\end{array}$ & N/A \\
\hline
\end{tabular}

diagnosis of MKD in a recent French study of 13 patients [26]. MKD appeared to affect both men and women equally $[1,2,8-10,17]$.

MKD is characterized by recurrent inflammatory attacks, with abrupt onset of high fever (frequently exceeding $40{ }^{\circ} \mathrm{C}$ ) as the most noted symptom, and each episode lasts 3 to 7 days in most patients [1,5]. Fever episodes occur spontaneously but also can be precipitated by vaccination, infection, or physical and emotional stress $[2,5,8,17]$. Fever episodes occur irregularly every 2 to 8 weeks in HIDS patients [1] and with greater frequencies in MVA patients than in HIDS patients, with the former (MVA) reporting as often as 25 episodes and the latter (HIDS) averaging 12 annually [9, 17, 27].

Febrile attacks are frequently accompanied by a variety of signs and symptoms, including gastrointestinal complaints such as abdominal pain, diarrhea and vomiting; lymphoid tissue symptoms such as lymphadenopathy (mainly in the cervical region) and splenomegaly; musculoskeletal symptoms such as arthralgia and arthritis (mainly in large peripheral joints) and myalgia; cutaneous and mucocutaneous symptoms such as maculopapular rash, aphthous ulcers (or stomatitis) and pharyngitis; and other symptoms such as headache, cold chills, malaise and fatigue $[2,8,17]$ (Table 1). All HIDS patients who had splenomegaly also had lymphadenopathy concurrently in the International HIDS Database [8]. Hepatomegaly was reported in $22 \%$ of HIDS patients in the International HIDS Database [8], and the frequency of hepatomegaly was $25-37 \%$ in MKD patients in the French and Belgian study [2] (Table 1). Hepatosplenomegaly was reported in the majority of patients with MVA in a European cohort of 11 MVA children [27]. Rare cases of cholestatic or non- cholestatic hepatitis have also been described in a few children with MKD [28-33]. Rare instances of macrophage activation syndrome, a life-threatening complication characterized by high fever, pancytopenia and liver dysfunction, have been reported during febrile attacks [2, 17]. Additional clinical features of MVA, the more severe form of MKD, include intrauterine growth retardation, various congenital defects (cataracts, shortened limbs, and dysmorphic craniofacial features), failure to thrive, neurological involvement (psychomotor retardation, developmental delay, progressive cerebellar ataxia, and hypotonia) $[1,27]$.

Febrile attacks are most frequent in childhood and decrease with age $[8,9]$, while disease activity will continue to be present in most affected patients $[2,8,9]$. In the International HIDS Database [8], the percentage of HIDS patients with $>6$ febrile attacks per year was approximately $90 \%$ in the first decade of life and $73 \%$ in the second decade of life. After the age of 20 years, $50 \%$ of the HIDS patients remained to have $>6$ attacks per year. Furthermore, the percentage of HIDS patients with $>12$ febrile attacks per year was $44 \%$ in the first decade of life, $24 \%$ in the second decade of life, and $18 \%$ over the age of 20 years. However, no patients had a remission [8]. In the French and Belgian study, 14 (45\%) of the 31 surviving symptomatic patients followed up for $>5$ years turned into asymptomatic or showed only mildly active disease and had a significant reduction in the frequency of febrile attacks (disease activity score of 0 [inactive disease] or 1 [mild] by the physician's global subjective assessment of disease activity) without longterm treatment [2]. However, the other 17 of the 31 surviving symptomatic patients (55\%) in this study continued to have highly active disease as demonstrated by 
frequent febrile attacks or continuous organ involvement (disease activity score of 2 [severe]) [2]. There was no significant difference in mean age at disease onset ( $8.2 \mathrm{vs}$ 12.2 months) or the frequency of the p.Val377lle mutation (70 \% vs $57 \%$ ) between patients with the persistently high disease activity or fatal outcome and those with the decreased disease activity over time [2]. In the Italian study, the number of fever episodes per year decreased from $13.8 \pm 5.4$ at baseline to $8.8 \pm 6.7$ at the follow-up. While 12 patients (29\%) displayed a spontaneous improvement of the disease (a reduction of $>30 \%$ of fever episodes or no fever episodes in the last 6 months without any maintenance therapy) at the follow-up, 15 (36 \%) showed no changes, and 7 (17\%) were exacerbated [9]. In multivariate analysis, female sex and the homozygous state for p.Val377Ile were found to be significantly associated with the spontaneous improvement of disease course in patients with MKD [9].

MKD, including milder HIDS phenotype, is also associated with long-term complications. Type AA amyloidosis (3\% [frequency]), joint contractures (4\%), and abdominal adhesions (10\%) were reported in patients with HIDS in the International HIDS Database [8]. All 3 patients who developed amyloidosis experienced recurrent febrile attacks for over 20 years prior to the manifestation of amyloidosis [8]. Type AA amyloidosis (5\%) was also found in patients with MKD in the Eurofever registry [17]. In the French and Belgian study, although type AA amyloidosis was not observed, among 49 symptomatic patients with MKD, 27 patients (55\%) had chronic neurologic, abdominal, renal, pulmonary, endocrine, cutaneous, ocular, or hematologic involvement, erosive polyarthritis, and/or Sjögren's syndrome; 13 patients $(27 \%)$ had recurrent and/or severe infections including otitis, sinusitis, and pneumonitis with at least 3 severe pneumococcal infections (6\%); and 3 patients (6\%) developed renal angiomyolipoma [2].

\section{Biomarkers}

During febrile attacks in patients with HIDS [8] or MKD [2], there is a strong acute-phase response, with substantially elevated concentrations of white blood cell (WBC) count, C-reactive protein (CRP), and erythrocyte sedimentation rate (ESR), especially CRP and ESR (Table 1). CRP, ESR and WBC count are nonspecific markers of systemic inflammation [34]. Between febrile attacks in patients with HIDS in the International HIDS Database, the concentrations of these inflammatory biomarkers decreased, but continued to be elevated in some patients [8]. Similarly, a study showed that pro-inflammatory cytokines such as IL$1 \beta$ and IL- 6 were significantly increased in MKD patients $(n=8)$ even during the non-acute phase as compared to healthy controls $(n=35)$ [35].
Most patients with HIDS have elevated concentrations of IgD and IgA (Table 1). Although an elevated IgD concentration may suggest a possible diagnosis of HIDS, it is not diagnostic as some patients do not have an elevated IgD concentration $[2,8,17]$. The percentage of the patients with abnormal values of $\operatorname{IgD}$ was $78 \%$ in the International HIDS Database [8], $88 \%$ in the French and Belgian study [2], and $72 \%$ in the Eurofever registry [17]. The diagnostic value of an elevated IgD concentration in patients with recurrent fever and clinical signs suggestive of MKD was found to be suboptimal, with a sensitivity of $79 \%$, a specificity of $27 \%$, a positive predictive value of $50 \%$, and a negative predictive value of $58 \%$ [36]. An elevated IgD concentration is often accompanied by an elevated IgA, but the elevation in IgA is also not present in some patients (64\% of tested patients above $2.6 \mathrm{~g} / \mathrm{L}$ in the International HIDS Database [8] and $57 \%$ of tested patients $>3 \mathrm{~g} / \mathrm{L}$ in the French and Belgian study [2]).

There is a residual mevalonate kinase activity varying from $1.8 \%$ to $28 \%$ in HIDS patients, but little to no residual activity in MVA patients [1,27]. Conversely, there are mildly to moderately elevated urinary mevalonic acid concentrations in patients with HIDS, but very high concentrations in plasma and urine in patients with MVA $[1,2,27]$. In a European cohort of 11 MVA children, plasma and urinary mevalonic acid concentrations were reported to be correlated with the severity of the clinical disease among patients and during the course of remission and exacerbation within patients [27]. Thus, the mevalonic acid concentration is a good indicator of the severity of the disease. All 33 MKD patients tested during febrile attacks in the French and Belgian study [2] and 37 of the 40 patients tested (93\%) in the Eurofever registry [17] had elevated urinary mevalonic acid concentrations, suggesting that the mevalonic acid concentration is also a sensitive biomarker for the screening of MKD [2]. The diagnostic value of the urinary mevalonic acid measurement in patients with a clinical suspicion of MKD was evaluated in a retrospective analysis of data from a single center in the Netherlands [37]. The analysis found a sensitivity of $92 \%$, a specificity of $90 \%$, a positive predictive value of $71 \%$, and a negative predictive value of $98 \%$, further indicating that the urinary mevalonic acid measurement is a reasonable biomarker to screen patients for MVK genetic testing and enzyme assay [37].

\section{Prognosis and survival}

HIDS, the less severe form of MKD, is not typically lifethreatening and is not in general related to a decrease in life expectancy [38]. While mildly affected patients with MVA may have a normal life expectancy [38], the most severely affected patients with MVA can die in early 
childhood [27, 38]. In the International HIDS Database, there were three deaths during the follow-up, but the causes of death (suicide, cerebral hemorrhage, and pneumococcal sepsis) were considered to be unrelated to HIDS [8]. In the French and Belgian study, which included both the mild and severe phenotypes of MKD, three patients died of causes associated with MKD at age of 2 to 3 years - two patients died of multiple organ failure and one patient died of staphylococcal sepsis associated with macrophage activation syndrome [2]. In a European cohort of 11 MVA children, 4 patients died during recurrent crises at age of 6 months to 4 years, and two of them had exceedingly high plasma and urinary mevalonic acid concentrations [27], suggesting that the mevalonic acid measurement may also potentially serve as a prognostic biomarker.

\section{Health-related quality of life (HRQOL)}

HIDS significantly impairs several aspects of patients' and caregivers' quality of life [8, 39-41], including physical role functioning, social functioning, emotion, and finance, with an adverse impact on patients' daily activities, education, employment status, independence, and family life $[8,39,41]$. Due to its rarity and nonspecific clinical manifestations, a number of alternative diagnoses and medical referrals may occur before the MKD diagnosis $[8,10,26]$, which further augment the burden of the disease on both the patient and patient's family. Thus, early diagnosis and treatment are critical in improving HRQOL.

Living with HIDS is unpleasant. During inflammatory attacks, patients experience high fever, nausea (especially in children), and pain $[8,39]$ and are often bedridden during severe flares [39]. A survey of HIDS patients in the US, Europe, and Australia also revealed that HIDS adversely affected patients' relationships and social lives through limiting their activities, and for caregivers and adult patients, inflammatory attacks and doctor appointments caused missed work and limited career options, resulting in financial dependency [39]. In the International HIDS Database, HIDS was also reported to interfere with the development of autonomy and social development during childhood probably due to the increased dependency on caregivers and the decreased participation in peer and school activities because of their disease. Additionally, HIDS was reported to delay their education in $46 \%$ of the patients and to make the high school graduation unachievable in $17 \%$. Moreover, $35 \%$ of the patients reported that HIDS contributed to their loss of job. Furthermore, $27 \%$ of the patients were unemployed at the time of the study, which was much higher than the unemployment rate in the general Dutch population. The negative impact on HRQOL by HIDS was correlated with the number of inflammatory attacks.
HIDS patients who had $>6$ inflammatory attacks per year had significantly lower scores for the domains of pain, physical role functioning, and general health perception than those who had 6 or less attacks per year in the International HIDS Database [8].

\section{Response to treatment}

Currently, there are no therapies approved for MKD [1]. A number of treatments have been tried to treat and prevent febrile attacks in some patients $[1,2,8,18]$ (Table 2). In the Eurofever registry, nonsteroidal antiinflammatory drugs (NSAIDs) and corticosteroids were the most frequently used medications (39 and 33 of the 67 patients [ $58 \%$ and $49 \%$ ], respectively) and were primarily administered as on demand therapy [18]. NSAIDs were mostly taken during febrile attacks and relieved symptoms in most patients [5] and resulted in a complete response in $5(13 \%)$ and a partial response in 25 (64. \%) in the Eurofever registry [18]. Corticosteroids given in high dosage can reduce the duration of febrile attacks [18]. Corticosteroids provided a complete response in $8(24 \%)$ and a partial response in $22(67 \%)$ in the Eurofever registry and a partial response in 35 (63\%), but no complete response in combined data of 187 patients from a literature review by the Eurofever registry investigators [18]. Anakinra, an IL-1 receptor antagonist, was used in 27 of the 67 patients (40\%) in the Eurofever registry and the response was complete in $6(22 \%)$ and partial in $18(67 \%)$ in the Eurofever registry and was complete in 12 (34\%) and partial in 16 (46\%) from the literature review [18]. Etanercept, a tumor necrosis factor alpha (TNF- $\alpha$ ) inhibitor, was used in 17 of the 67 patients ( $25 \%$ ) in the Eurofever registry and induced a complete or partial response in 55-65\% of the patients who were treated [18]. Canakinumab (a fully human anti-IL-1 $\beta$ monoclonal antibody) and adalimumab (a TNF- $\alpha$ blocker), the newer biologic agents, also generated a complete or partial response in several patients $[18,42]$. The results from a recent open-label, single treatment arm study of canakinumab in 9 patients with active HIDS also showed a reduction in the frequency, duration, signs and symptoms of acute febrile episodes and the normalization of inflammatory markers [43]. Further, a recent literature review of the treatment of HIDS with biologics in children reported that complete or partial responses were $90 \%$ in 21 HIDS patients treated with anakinra, $50 \%$ in 16 HIDS patients treated with etanercept, and $100 \%$ in 5 patients treated with canakinumab [44]. However, colchicine, statins, antibiotics, thalidomide, and cyclosporine have not shown to be effective $[2,8,18]$.

Since few randomized controlled trials have been conducted, the available data on response to treatment are mostly derived from retrospective registries, case series, 
Table 2 Response to treatment in 67 patients with MKD from the Eurofever registry and in combined data of 187 patients from a literature review (19 papers) by the Eurofever registry investigators ${ }^{a}$

\begin{tabular}{|c|c|c|c|c|c|c|c|c|c|c|}
\hline \multirow[t]{2}{*}{ Medication } & \multirow[t]{2}{*}{ Data source } & \multirow[t]{2}{*}{ No. of patients } & \multicolumn{2}{|c|}{ Treated patients } & \multicolumn{2}{|c|}{ Complete response } & \multicolumn{2}{|c|}{ Partial response } & \multicolumn{2}{|c|}{ Failure } \\
\hline & & & No. & $\%$ & No. & $\%$ & No. & $\%$ & No. & $\%$ \\
\hline NSAIDs & Eurofever & 67 & 39 & $58 \%$ & 5 & $13 \%$ & 25 & $64 \%$ & 9 & $23 \%$ \\
\hline \multirow[t]{2}{*}{ Corticosteroids } & Eurofever & 67 & 33 & $49 \%$ & 8 & $24 \%$ & 22 & $67 \%$ & 3 & $9 \%$ \\
\hline & Literature & 187 & 56 & $30 \%$ & 0 & $0 \%$ & 35 & $63 \%$ & 21 & $38 \%$ \\
\hline \multirow[t]{2}{*}{ Colchicine } & Eurofever & 67 & 17 & $25 \%$ & 0 & $0 \%$ & 6 & $35 \%$ & 11 & $65 \%$ \\
\hline & Literature & 187 & 60 & $32 \%$ & 1 & $2 \%$ & 11 & $18 \%$ & 48 & $80 \%$ \\
\hline \multirow[t]{2}{*}{ Statins } & Eurofever & 67 & 11 & $16 \%$ & 0 & $0 \%$ & 3 & $27 \%$ & 8 & $73 \%$ \\
\hline & Literature & 187 & 31 & $17 \%$ & 0 & $0 \%$ & 10 & $32 \%$ & 21 & $68 \%$ \\
\hline \multirow[t]{2}{*}{ Anakinra } & Eurofever & 67 & 27 & $40 \%$ & 6 & $22 \%$ & 18 & $67 \%$ & 3 & $11 \%$ \\
\hline & Literature & 187 & 35 & $19 \%$ & 12 & $34 \%$ & 16 & $46 \%$ & 7 & $20 \%$ \\
\hline \multirow[t]{2}{*}{ Canakinumab } & Eurofever & 67 & 2 & $3 \%$ & 1 & $50 \%$ & 1 & $50 \%$ & 0 & $0 \%$ \\
\hline & Literature & 187 & 3 & $2 \%$ & 2 & $67 \%$ & 1 & $33 \%$ & 0 & $0 \%$ \\
\hline Rilonacept & Eurofever & 67 & 1 & $1 \%$ & 0 & $0 \%$ & 1 & $100 \%$ & 0 & $0 \%$ \\
\hline \multirow[t]{2}{*}{ Etanercept } & Eurofever & 67 & 17 & $25 \%$ & 1 & $6 \%$ & 10 & $59 \%$ & 6 & $35 \%$ \\
\hline & Literature & 187 & 27 & $14 \%$ & 6 & $22 \%$ & 9 & $33 \%$ & 12 & $44 \%$ \\
\hline Infliximab & Eurofever & 67 & 1 & $1 \%$ & 0 & $0 \%$ & 0 & $0 \%$ & 1 & $100 \%$ \\
\hline \multirow[t]{2}{*}{ Adalimumab } & Eurofever & 67 & 2 & $3 \%$ & 0 & $0 \%$ & 1 & $50 \%$ & 1 & $50 \%$ \\
\hline & Literature & 187 & 3 & $2 \%$ & 1 & $33 \%$ & 1 & $33 \%$ & 1 & $33 \%$ \\
\hline
\end{tabular}

Abbreviations: MKD mevalonate kinase deficiency, NSAIDs nonsteroidal anti-inflammatory drugs

${ }^{a}$ Adapted from ter Haar et al. [18]. Response to treatment was classified as complete remission, partial remission, failure or worsening. Complete remission was defined as no signs of active disease and the normalization of reported inflammatory markers, allowing for the persistence of sequelae. Some patients received more than one treatment

and case reports [18]. Although there is lack of highquality evidence, the existing data suggest that NSAIDs and corticosteroids on demand may confer some benefits for MKD patients and that patients with inadequately controlled MKD may benefit from IL-1 blockade or TNF- $\alpha$ inhibition $[8,18]$.

For severely affected patients who are resistant to all other therapies, allogeneic hematopoietic stem cell transplantation (HSCT) has been suggested as an option $[1,45]$. Several patients had successfully undergone allogeneic HSCT, with a remission of systemic inflammation and an improvement of neurological symptoms [31, 46, 47].

With respect to side effects associated with the repeated use of biologics in patients with MKD, pain and inflammation at the injection site, bacterial pneumonia, and herpes zoster infection have been reported for anakinra, injection site reaction, recurrent pharyngitis, and transient hepatitis for canakinumab, and upper respiratory infections for etanercept [44]. Long-term corticosteroid use is associated with a reduction in bone mineral accretion and an increased risk of osteopenia in children [48]. HSCT is associated with the inherent transplantation-related risks such as graft-versus-host disease $[1,46,49]$ and is suggested to be considered only in severely affected patients resistant to all other therapies $[1,45]$.

\section{Conclusions}

Symptoms of MKD, an 'ultra-rare' autosomal recessive autoinflammatory disease, usually begin within the first year of life, but there is a delay by several years in diagnosis. Recurrent febrile attacks are most frequent in childhood and decline with age. MKD impairs HRQOL of patients and their families with a negative impact on patients' daily activities, education, and employment. MKD is associated with serious long-term complications. Although MKD manifested as HIDS in general does not reduce life expectancy, MVA can be life-threatening and cause death in early childhood. Currently, there are no treatments approved for MKD. Off-label use of anti-IL-1 and anti-TNF- $\alpha$ agents and corticosteroids appears to provide some but insufficient benefits. There are concerns on side effects associated with the repeated use of these drugs, especially in children [44]. The development of therapies for MKD is thus needed.

\section{Abbreviations}

CRP: C-reactive protein; ESR: erythrocyte sedimentation rate; HIDS: hyperimmunoglobulinemia D syndrome; HRQOL: health-related quality of life; HSCT: hematopoietic stem cell transplantation; IgA: immunoglobulin A; IgD: immunoglobulin D; IL: interleukin; IPP: isopentenyl pyrophosphate; MKD: mevalonate kinase deficiency; MVA: mevalonic aciduria; MVK: mevalonate kinase; N/A: data not available; NSAIDs: nonsteroidal antiinflammatory drugs; TNF-a: tumor necrosis factor alpha; US: United States; WBC: white blood cell. 


\section{Competing interests}

The author is an employee of Takeda.

\section{Authors' contributions}

Shumin Zhang conducted literature review and drafted the manuscript.

\section{Funding}

This study was supported by Takeda.

\section{Received: 25 February 2016 Accepted: 27 April 2016}

\section{Published online: 04 May 2016}

\section{References}

1. van der Burgh R, Ter Haar NM, Boes ML, Frenkel J. Mevalonate kinase deficiency, a metabolic autoinflammatory disease. Clin Immunol. 2013;147: 197-206.

2. Bader-Meunier B, Florkin B, Sibilia J, Acquaviva C, Hachulla E, Grateau G, et al. Mevalonate kinase deficiency: a survey of 50 patients. Pediatrics. 2011;128:e152-9.

3. Posada de la Paz M, Villaverde-Hueso A, Alonso V, János S, Zurriaga Ó, Pollán M, Abaitua-Borda I. Rare Diseases Epidemiology Research. Adv Exp Med Biol. 2010;686:17-39.

4. Rare Diseases. Common Issues in Drug Development Guidance for Industry. FDA draft guidance for industry. 2015.

5. Ter Haar N, Lachmann H, Woo P, Simon A, Dolezalova P, Modesto C, et al. PReS-FINAL-2335: preliminary analysis of 85 patients with mevalonate kinase deficiency from the eurofever registry. Pediatr Rheumatol. 2013;11(2):325.

6. Haas D, Hoffmann GF. Mevalonate kinase deficiencies: from mevalonic aciduria to hyperimmunoglobulinemia D syndrome. Orphanet J Rare Dis. 2006;1:13

7. Mevalonate Kinase Deficiency/HIDS. In: Disorder Definitions. The Sterol and Isoprenoid Research (STAIR) Consortium. Rare Diseases Clinical Research Network. http://www.rarediseasesnetwork.org/cms/stair/Learn-More/ Disorder-Definitions. Accessed 24 Jan 2016.

8. van der Hilst JC, Bodar EJ, Barron KS, Frenkel J, Drenth JP, van der Meer JW, et al. Long-term follow-up, clinical features, and quality of life in a series of 103 patients with hyperimmunoglobulinemia D syndrome. Medicine (Baltimore). 2008:87:301-10.

9. Doglio M, Federici S, Tommasini A, Meini A, Cattalini M, Obici L, et al. PReSFINAL-2232: Long-term follow-up in a national cohort of MKD patients: search for clinical predictors of a spontaneous improvement. Ljubljana: 20th Pediatric Rheumatology European Society (PReS) Congress; 2013. Poster P222.

10. Toplak N, Frenkel J, Ozen S, Lachmann HJ, Woo P, Kone-Paut I, et al. An international registry on autoinflammatory diseases: the Eurofever experience. Ann Rheum Dis. 2012;71:1177-82.

11. HIDS. Autoinflammation. 2015. http://www.autoinflammatie.nl/ENG/folder6/ index.php. Accessed 24 Jan 2016.

12. Jesus AA, Fujihira E, Watase M, Terreri MT, Hilario MO, Carneiro-Sampaio M, et al. Hereditary autoinflammatory syndromes: a Brazilian multicenter study. J Clin Immunol. 2012;32:922-32.

13. Toplak N, Dolezalova P, Constantin T, Sediva A, Pasic S, Ciznar P, et al. Periodic fever syndromes in Eastern and Central European countries: results of a pediatric multinational survey. Pediatr Rheumatol Online J. 2010:8:29.

14. Simon A, Mariman EC, van der Meer JW, Drenth JP. A founder effect in the hyperimmunoglobulinemia D and periodic fever syndrome. Am J Med. 2003;114:148-52.

15. Vuch J, Marcuzzi A, Bianco AM, Tommasini A, Zanin V, Crovella S. Evolutionary hypothesis of the Mevalonate Kinase Deficiency. Med Hypotheses. 2013;80:67-9.

16. Lainka E, Neudorf U, Lohse P, Timmann C, Bielak M, Stojanov S, et al Incidence and clinical features of hyperimmunoglobulinemia $D$ and periodic fever syndrome (HIDS) and spectrum of mevalonate kinase (MVK) mutations in German children. Rheumatol Int. 2012;32:3253-60.

17. Jeyaratnam J, ter Haar N, Lachmann H, Simon A, Brogan P, Doglio M, et al. Genetic and phenotypic characteristics of 114 patients with mevalonate kinase deficiency. Pediatr Rheumatol. 2015;13 Suppl 1:25.

18. Ter Haar N, Lachmann H, Ozen S, Woo P, Uziel Y, Modesto C, et al. Treatment of autoinflammatory diseases: results from the Eurofever Registry and a literature review. Ann Rheum Dis. 2013;72:678-85.
19. Infevers: an online database for autoinflammatory mutations. International Society of Systemic Auto-Inflammatory Diseases. 2014. http://fmf.igh.cnrs.fr/ ISSAID/infevers/. Accessed 18 Feb 2016

20. Milhavet F, Cuisset L, Hoffman HM, Slim R, El-Shanti H, Aksentijevich I, et al. The infevers autoinflammatory mutation online registry: update with new genes and functions. Hum Mutat. 2008;29:803-8.

21. Touitou I, Lesage S, McDermott M, Cuisset L, Hoffman H, Dode C, et al. Infevers: an evolving mutation database for auto-inflammatory syndromes. Hum Mutat. 2004;24:194-8.

22. D'Osualdo A, Picco P, Caroli F, Gattorno M, Giacchino R, Fortini P, et al. MVK mutations and associated clinical features in Italian patients affected with autoinflammatory disorders and recurrent fever. Eur J Hum Genet. 2005:13:314-20.

23. Mandey SH, Schneiders MS, Koster J, Waterham HR. Mutational spectrum and genotype-phenotype correlations in mevalonate kinase deficiency. Hum Mutat. 2006;27:796-802

24. Cuisset L, Drenth JP, Simon A, Vincent MF, van der Velde Visser S, van der Meer JW, et al. Molecular analysis of MVK mutations and enzymatic activity in hyper-lgD and periodic fever syndrome. Eur J Hum Genet. 2001;9:260-6.

25. Berg S, Fasth A. Autoinflammatory disorders. In: Rezaei N, Aghamohammadi A, Notarangelo LD, editors. Primary immunodeficiency diseases: definition, diagnosis, and management. Verlag Berlin Heidelberg: Springer; 2008. p. 215-33.

26. Berody S, Galeotti C, Kone-Paut I, Piram M. A restrospective survey of patients's journey before the diagnosis of mevalonate kinase deficiency. Joint Bone Spine. 2015;82:240-4.

27. Hoffmann GF, Charpentier C, Mayatepek E, Mancini J, Leichsenring M, Gibson KM, et al. Clinical and biochemical phenotype in 11 patients with mevalonic aciduria. Pediatrics. 1993;91:915-21.

28. Leyva-Vega M, Weiss PF, Ganesh J, Conlin L, Spinner NB, Matthews RP. Significant liver disease in a patient with $\mathrm{Y} 116 \mathrm{H}$ mutation in the MVK gene. Am J Med Genet A. 2011:155A:1461-4.

29. Tahara M, Sakai H, Nishikomori R, Yasumi T, Heike T, Nagata I, et al. Patient with neonatal-onset chronic hepatitis presenting with mevalonate kinase deficiency with a novel MVK gene mutation. Mod Rheumatol. 2011:21:641-5.

30. Hinson DD, Rogers ZR, Hoffmann GF, Schachtele M, Fingerhut R, Kohlschutter A, et al. Hematological abnormalities and cholestatic liver disease in two patients with mevalonate kinase deficiency. Am J Med Genet. 1998;78:408-12

31. Chaudhury S, Hormaza L, Mohammad S, Lokar J, Ekong U, Alonso EM et al. Liver transplantation followed by allogeneic hematopoietic stem cell transplantation for atypical mevalonic aciduria. Am J Transplant. 2012;12:1627-31.

32. Steiner LA, Ehrenkranz RA, Peterec SM, Steiner RD, Reyes-Mugica M, Gallagher PG. Perinatal onset mevalonate kinase deficiency. Pediatr Dev Pathol. 2011:14:301-6.

33. Schulert GS, Bove K, McMasters R, Campbell K, Leslie N, Grom AA. 11month-Old infant with periodic fevers, recurrent liver dysfunction, and perforin gene polymorphism. Arthritis Care Res (Hoboken). 2015;67:1173-9.

34. Gabay C, Kushner I. Acute-phase proteins and other systemic responses to inflammation. N Engl J Med. 1999;340:448-54.

35. Marcuzzi A, Zanin V, Kleiner G, Monasta L, Crovella S. Mouse model of mevalonate kinase deficiency: comparison of cytokine and chemokine profile with that of human patients. Pediatr Res. 2013;74:266-71.

36. Ammouri W, Cuisset L, Rouaghe S, Rolland MO, Delpech M, Grateau G, et al. Diagnostic value of serum immunoglobulinaemia $D$ level in patients with a clinical suspicion of hyper lgD syndrome. Rheumatology (Oxford). 2007:46:1597-600

37. Jeyaratnam J, Ter Haar NM, de Sain-van der Velden MG, Waterham HR, van Gijn ME, Frenkel J. Diagnostic value of urinary mevalonic acid excretion in patients with a clinical suspicion of mevalonate kinase deficiency (MKD). JIMD Rep. 2015

38. Mevalonate kinase deficiency. In: Genetics Home Reference. 2016. http://ghr.nlm.nih.gov/condition/mevalonate-kinase-deficiency. Accessed 24 Jan 2016.

39. Dandekar P, Gregson J, Campbell R, Bourhis F. Hyper Immunoglobulin D syndrome (HIDS): understanding what it is like to live with this rare condition. Pediatr Rheumatol. 2015;13 Suppl 1:24.

40. Federici S, Tomasini A, Meini A, Doglio M, Calcagno G, Zulian F, et al. Impact of mevalonate kinase deficiency (MKD) on the quality of life in 
children and young adults: a national multicentre study. Pediatr Rheumatol. 2011;9 Suppl 1:24.

41. van der Hilst JC, Frenkel J. Hyperimmunoglobulin D syndrome in childhood. Curr Rheumatol Rep. 2010:12:101-7.

42. Di Gangi M, Amato G, Converso G, Benenati A, Leonetti C, Borella E, et al. Long-term efficacy of adalimumab in hyperimmunoglobulin $D$ and periodic fever syndrome. Isr Med Assoc J. 2014;16:605-7.

43. Aróstegui JI, Anton J, Calvo I, Robles A, Speziale A, Joubert Y, et al. Long-term efficacy and safety of Canakinumab in active Hyper-lgD syndrome (HIDS): results from an open-label study. Pediatr Rheumatol. 2015;13 Suppl 1:058.

44. Kostjukovits S, Kalliokoski L, Antila K, Korppi M. Treatment of hyperimmunoglobulinemia D syndrome with biologics in children: review of the literature and Finnish experience. Eur J Pediatr. 2015;174:707-14.

45. ter Haar NM, Oswald M, Jeyaratnam J, Anton J, Barron KS, Brogan PA, et al. Recommendations for the management of autoinflammatory diseases. Ann Rheum Dis. 2015;74:1636-44.

46. Arkwright PD, Abinun M, Cant AJ. Mevalonic aciduria cured by bone marrow transplantation. N Engl J Med. 2007;357:1350.

47. Neven B, Valayannopoulos V, Quartier P, Blanche S, Prieur AM, Debre M, et al. Allogeneic bone marrow transplantation in mevalonic aciduria. N Engl J Med. 2007:356:2700-3.

48. Kelly HW, Van Natta ML, Covar RA, Tonascia J, Green RP, Strunk RC. Effect of long-term corticosteroid use on bone mineral density in children: a prospective longitudinal assessment in the childhood Asthma Management Program (CAMP) study. Pediatrics. 2008;122:e53-61.

49. Hugle T, van Laar JM. Allogeneic stem cell transplantation for rheumatic autoimmune diseases. F1000 Med Rep. 2010;2:22.

\section{Submit your next manuscript to BioMed Central and we will help you at every step:}

- We accept pre-submission inquiries

- Our selector tool helps you to find the most relevant journal

- We provide round the clock customer support

- Convenient online submission

- Thorough peer review

- Inclusion in PubMed and all major indexing services

- Maximum visibility for your research

Submit your manuscript at www.biomedcentral.com/submit 